\title{
PENEGAKAN HUKUM ADMINISTRASI TERHADAP ALIH FUNGSI HUTAN MANGROVE DI KABUPATEN POHUWATO DALAM MEWUJUDKAN PEMBANGUNAN BERWAWASAN LINGKUNGAN
}

\author{
Ervina Yulianti Mohamad \\ Email: vinamohamad17@gmail.com \\ Mahasiswa Program Magister Ilmu Hukum Program Pascasarjana \\ Fakultas Hukum Universitas Sebelas Maret Surakarta \\ Albertus Sentot Sudarwanto \\ Email: alsentotsudarwanto@yahoo.com \\ I Gusti Ayu Ketut Rachmi Handayani \\ Email: ayu_igk@yahoo.com \\ Dosen Fakultas Hukum Universitas Sebelas Maret Surakarta
}

\begin{abstract}
This paper aims to determine the law enforcement of the administration of the transfer of mangrove forest function in Pohuwato Regency with reference to the provisions of Article 36 of Law Number 32 Year 2009 on Environmental Protection and Management, Government Regulation No. 27 of 2012 on Environmental Permits and Regional Regulations Number 13 Year 2013 on Mangrove Ecosystem Management. This research is an empirical legal research supported by approach of law and case approach. The results showed that the total area of mangrove forest based on the function in Pohuwato Regency are 15,600,81 ha while the mangrove forest area that has been converted into dyke is 7,679.64 ha. In Local Regulation No. 13 of 2013 on Mangrove Ecosystem Management determines the area that can be used as a pond business, namely limited protected area of no more than 5 percent of the total area and fishery cultivation area contained in other areas of use. From the data obtained all the ponds in the mangrove forest area does not have the environmental permit required by Law Number 32 Year 2009 on Environmental Protection and Management.
\end{abstract}

Keywords: The Law Enforcement Administration, Mangrove Forest Function Transfer, Environmentally Friendly Development

\begin{abstract}
Abstrak
Tulisan ini bertujuan untuk mengetahui penegakan hukum administrasi terhadap alih fungsi hutan mangrove di Kabupaten Pohuwato dengan mengacu pada ketentuan Pasal 36 Undang-Undang Nomor 32 Tahun 2009 tentang Perlindungan dan Pengelolaan Lingkungan Hidup, Peraturan Pemerintah Nomor 27 Tahun 2012 tentang Izin Lingkungan dan Peraturan Daerah Nomor 13 Tahun 2013 tentang Pengelolaan Ekosistem Mangrove. Penelitian ini merupakan penelitian hukum
\end{abstract}


empiris didukung pendekatan perudang-undangan dan pendekatan kasus. Hasil penelitian menunjukkan dari total luas kawasan hutan mangrove berdasarkan fungsi di Kabupaten Pohuwato yaitu 15.600,81 Ha sedangkan kawasan hutan mangrove yang sudah beralih fungsi menjadi usaha tambak yaitu 7.679,64 ha. Dalam Perda Nomor 13 Tahun 2013 tentang Pengelolaan Ekosistem Mangrove menentukan kawasan yang bisa dijadikan usaha tambak yaitu kawasan lindung terbatas tidak lebih dari 5 persen total kawasan dan kawasan budidaya perikanan yang terdapat di areal penggunaan lain. Dari data yang diperoleh semua usaha tambak di kawasan hutan mangrove tidak memiliki izin lingkungan yang dipersyaratkan oleh Undang-Undang Nomor 32 Tahun 2009 tentang Perlindungan dan Pengelolaan Lingkungan Hidup.

\section{Kata Kunci: Penegakan Hukum Administrasi, Alih Fungsi Hutan Mangrove, Pembangunan Berwawasan Lingkungan}

\section{A. Pendahuluan}

Tulisan ini bermaksud menjelasakan tentang penegakan sanksi administrasi terhadap alih fungsi kawasan hutan mangrove yang dijadikan usaha tambak di Kabupaten Pohuwato, hal ini mengingat bahwa usahausaha tambak dikawasan hutan mangrove tidak memiliki izin lingkungan. Perlindungan dan pengelolaan lingkungan hidup berdasarkan Pasal 1 ayat (2) Undang-Undang Nomor 32 Tahun 2009 tentang Perlindungan dan Pengelolaan Lingkungan Hidup (selanjutnya disebut UUPPLH) adalah upaya sistematis dan terpadu yang dilakukan untuk melestarikan fungsi lingkungan hidup dan mencegah terjadinya pencemaran dan/atau kerusakan lingkungan hidup yang meliputi perencanaan, pemanfaatan, pengendalian, pemeliharaan, pengawasan dan penegakan hukum.

Pelaksanaan pembangunan dalam kaitannya dengan lingkungan dan tata ruang yang selama ini cenderung tidak terencana dan tidak berkelanjutan telah berdampak pada menurunnya kualitas dan fungsi lingkungan termasuk sumber daya alam didalamnya (Maret Priyanta, 2015: 341). Kerusakan sumber daya alam banyak disebabkan oleh aktivitas manusia. Banyak kasus-kasus pencemaran dan kerusakan lingkungan yang diakibatkan oleh aktivitas manusia seperti pencemaran

udara, pencemaran air, pencemaran tanah serta kerusakan hutan yang akhirnya merugikan manusia itu sendiri. 
Alih fungsi kawasan hutan merupakan permasalahan yang marak terjadi Indonesia. Pasal 19 Undang-Undang Nomor 41 Tahun 1999 tentang Kehutanan menyebutkan bahwa alih fungsi adalah perubahan peruntukan dan fungsi kawasan hutan. Perubahan peruntukan kawasan hutan terjadi melalui proses tukar-menukar kawasan hutan dan pelepasan kawasan hutan.

Pada dasarnya kawasan hutan dapat dimanfaatkan dengan tetap memperhatikan sifat, karakteristik, dan kerentanannya, serta tidak dibenarkan mengubah suatu kawasan hutan yang memiliki fungsi perlindungan, dan harus dilakukan kajian yang mendalam serta komperhensif. Dalam pemanfaatan kawasan hutan harus disesuaikan dengan fungsi pokoknya yaitu fungsi konservasi, lindung dan produksi.

Kesesuaian ketiga fungsi tersebut sangat dinamis dan yang paling penting yaitu agar dalam pemanfaatannya harus tetap sinergi. Meski secara normatif, konversi atau perubahan kawasan hutan tidak dilarang oleh undang-undang, namun untuk menjaga kualitas lingkungan, sejauh mungkin dihindari terjadinya konversi/perubahan terhadap hutan alam yang masih produktif, guna menghindari kerusakan kawasan hutan (Suttan Iskandar, 2011: 533).

Dalam pengelolaan lingkungan hidup terdapat hubungan antara lingkungan hidup dengan beberapa bidang lainnya seperti perindustrian, kehutanan, dan pertambangan. Konsekuensi dari hubungan bidang-bidang tersebut terletak pada izin usaha dari tiap bidang yang harus memiliki izin lingkungan. Hal ini sesuai dengan amanat Pasal 36 ayat (1) UUPPLH yaitu"setiap usaha dan/atau kegiatan yang wajib memiliki AMDAL atau UKL-UPL wajib memiliki izin lingkungan". Hal ini berarti bahwa UUPPLH menjadi payung hukum bagi peraturan perundang-undangan lainnya.

Penegakan hukum lingkungan berkaitan erat dengan kemampuan aparatur dan kepatuhan masyarakat terhadap peraturan yang berlaku. Dalam UUPPLH terdapat tiga bidang penegakan hukum yaitu: Penegakan 
hukum administrasi, Penegakan hukum pidana, dan Penegakan hukum perdata. Penegakan hukum lingkungan menjadi permasalahan saat menentukan upaya hukum apa yang dapat dilakukan dalam penyelesian suatu kasus lingkungan. UUPPLH dalam penjelasan umum ayat (6) menegaskan bahwa penegakan hukum pidana dalam memperkenalkan ancaman hukuman minimum di samping maksimum, perluasan alat bukti, pemidaan bagi pelanggaran baku mutu, keterpaduan penegakan hukum pidana, dan pengaturan tindak pidana korporasi. Penegakan hukum pidana lingkungan tetap memperhatikan asas ultimum remedium yang mewajibkan penerapan penegakan hukum pidana sebagai upaya terakhir setelah penerapan penegakan hukum administrasi dianggap tidak berhasil (Maret Priyanta, 2012: 361).

Kabupaten pohuwato adalah salah satu Kabupaten di Provinsi Gorontalo yang memiliki hutan mangrove terbesar dengan luas 15.600 hektare. Menurut Surat Keputusan Menteri Kehutanan No. 325/MenhutII/2010 tentang Penunjukan Kawasan Hutan di Provinsi Gorontalo. Pohuwato memiliki 473.273 hektare kawasan hutan dan 15.600 hektare diantaranya merupakan hutan mangrove. (http://www.antaranews. com/berita/504319/8233-hektare-lahanmangrove-pohuwato-beralih-fungsi diakses tanggal 17 Maret 2017). Kawasan hutan mangrove di Kabupaten Pohuwato kurang lebih 52,76 persen telah mengalami kerusakan dan degradasi yang cukup parah. Hal ini disebabkan karena adanya perambahan, konservasi hutan yang saat ini banyak di jadikan lahan pemukiman, usaha pertambakan, pertanian, dan penebangan.

Ekosistem hutan mangrove adalah hutan dengan ciri khas tertentu, yang mempunyai fungsi pokok perlindungan sistem penyangga kehidupan, sebagai kawasan pengawetan keanekaragaman tumbuhan swasta, serta pemanfaatan secara lestari sumber daya alam hayati dan ekosistemnya. Ekosistem hutan mangrove merupakan salah satu sumber daya alam hayati yang tergolong sebagai hutan konservasi (Muazzin dan Tinianus, 2010: 638). 
Perlindungan terhadap pelestarian kawasan hutan mangrove di Kabupaten pohuwato semakin berkurang. Kawasan hutan mangrove di Pohuwato banyak di jadikan usaha budidaya perikanan pola tambak oleh masyarakat maupun pelaku usaha. Kegiatan usaha tambak yang semakin meningkat berbanding lurus dengan kerusakan lingkungan di kawasan hutan mangrove. Dari data Dinas Lingkungan Hidup Kabupaten Pohuwato mempunyai kawasan hutan mangrove sebesar 15,600.81 hektare. Terdiri dari hutan lindung, hutan produksi, cagar alam, dan area penggunaan lain (APL). Sedangkan hutan mangrove yang beralih fungsi menjadi lahan tambak sebesar 7,679.64 hektare.

Alih fungsi secara besar-besaran di kawasan hutan mangrove juga terjadi di kawasan cagar alam dan hutan lindung. Padahal secara jelas dalam Undang-Undang Nomor 41 Tahun 1999 tentang Kehutanan disebutkan kawasan hutan sesuai dengan fungsinya dikategorikan dalam kawasan lindung dan kawasan budidaya, tetapi pada faktanya kawasan cagar alam Tanjung Panjang beralih fungsi menjadi lahan usaha tambak. Data Dinas Lingkungan Hidup kawasan cagar alam seluas 3.000 ha, hanya tinggal tersisa 15 persen saja yang masih utuh sementara 85 persen telah mengalami kerusakan. Selain itu faktor lain yang juga menyebabkan makin rusaknya kawasan hutan mangrove yaitu beralih fungsinya kawasan hutan yang dijadikan usaha tambak oleh masyarakat dan tidak memiliki izin lingkungan.

Dalam Peraturan Daerah Nomor 13 Tahun 2013 tentang Pengelolaan Ekosistem Mangrove di Kabupaten Pohuwato (Selanjutnya disebut Perda Kabupaten Pohuwato tentang Pengelolaan ekosistem Mangrove), Pasal 10 dijelaskan kawasan hutan mangrove ditetapkan sebagai berikut: Kawasan Lindung, Kawasan Lindung Terbatas, Kawasan Semapadan Sungai dan Pantai, Kawasan Budidaya Perikanan Tumpang Sari. Pada Pasal 11 ditentukan kegiatan pertambakan yang boleh dilaksanakan di dalam kawasan yaitu terdapat pada kawasan lindung 
terbatas dan kawasan budidaya. Dalam kawasan lindung terbatas disebutkan budidaya ikan/udang dengan model tambak tumpang sari dalam luasan terbatas (tidak lebih 5\% dari total luas hutan lindung terbatas). Di kawasan budidaya yang masuk dalam Area Penggunaan Lain (APL) dapat dilakukan budidaya ikan/udang dengan model tambak tumpang sari (Sylvo-fishery).

Dalam hal membuka usaha tambak dalam kawasan hutan lindung terbatas dan kawasan budidaya sebagaimana disebutkan dalam Pasal 11 Perda Mangrove harus mendapat izin dari pemerintah. Faktanya berdasarkan data dari Dinas Lingkungan Hidup semua usaha tambak di kawasan hutan mangrove baik dalam kawasan Hutan Lindung, Cagar Alam, Hutan Produksi, dan APL tidak memiliki izin usaha maupun izin lingkungan.

Kecenderungan alih fungsi hutan mangrove menjadi tambak yang semakin luas harus mendapat perhatian dan penanganan khusus oleh pemerintah daerah baik dalam bentuk kebjiakan maupun penegakan hukumya. Sebab hutan mangrove berperan penting dalam pelestarian lingkungan, untuk itu harus ada solusi agar kawasan hutan mangrove baik dalam wilayah cagar alam, hutan lindung, hutan produksi, dan APL yang telah beralih fungsi bisa dikembalikan sesuai peruntukannya. Berdasarkan hal-hal tersebut diatas, tulisan ini akan mengkaji penegakan hukum administrasi terhadap alih fungsi hutan mangrove di Kabupaten Pohuwato dalam mewujudkan pembangunan berwawasan lingkungan.

\section{B. Metode Penelitian}

Penelitian ini merupakan penelitian hukum empiris yang menggunakan data primer melalui penelitian lapangan di Kabupaten Pohuwato dengan lokasi penelitian di Dinas Lingkungan Hidup Kabupaten Pohuwato dan Kesatuan Pengelolaan Hutan Provinsi Gorontalo. Kemudian data sekunder menggunakan studi kepustakaan dengan metode dokumentasi, sedangkan data penelitian lapangan berasal dari wawancara 
dengan menggunakan alat pengumpulan data yaitu pedoman wawancara. Data primer dan sekunder yang diperoleh dari penelitian kepustakaan dan lapangan dianalisis dengan menggunakan metode kualitatif (Setiono, 2005: 5).

\section{Hasil Penelitian dan Pembahasan}

1. Kegiatan Usaha Wajib Izin Lingkungan yang tidak Menaati UndangUndang Nomor 32 Tahun 2009 Tentang PPLH

Kabupaten Pohuwato memiliki kawasan hutan mangrove terluas di Provinsi Gorontalo yaitu seluas $\pm 15.600,81$ ha yang terdiri dari Hutan lindung $\pm 6.829,92 \mathrm{Ha}$, Cagar Alam $\pm 3.204,30$ dan Areal Penggunaan lain seluas 5.566,46 Ha. Lebih lanjut berdasarkan Data Dinas Perikanan dan Kelautan Kabupaten Pohuwato tahun 2010 wilayah Kabupaten Pohuwato memiliki 62 pulau-pulau kecil, panjang garis pantai 86 mil atau $164 \mathrm{Km}$, luas perairan teritorial $\pm 3.292,71 \mathrm{KM}^{2}$, luas ekosistem mangrove saat ini 9.083 ha, luas kawasan terumbu karang $2.747,81$ ha dan luas padang lamun 975,92 ha. Berikut ini data yang diperoleh penulis dari Kesatuan Pengelolaan Hutan Provinsi Gorontalo wilayah Kabupaten Pohuwato :

Tabel. 1

Luas Kawasan Hutan Mangrove Berdasarkan Fungsi Di Kabupaten Pohuwato

\begin{tabular}{|l|l|c|c|c|c|c|}
\hline No & Kecamatan & $\begin{array}{c}\text { Hutan } \\
\text { Lindung }\end{array}$ & $\begin{array}{c}\text { Cagar } \\
\text { Alam }\end{array}$ & $\begin{array}{c}\text { Hutan } \\
\text { Produksi }\end{array}$ & APL & $\begin{array}{c}\text { Grand } \\
\text { Total }\end{array}$ \\
\hline 1 & Paguat & 251,83 & 60,31 & 24,02 & 270,72 & 606,88 \\
\hline 2 & Marisa & 0 & 253,55 & 1,31 & 263,73 & 518,59 \\
\hline 3 & Duhiadaa & 436,72 & 0 & 0 & $1.197,48$ & $1.634,20$ \\
\hline 4 & Patilanggio & 616,22 & 0 & 0 & 436,64 & $1.052,86$ \\
\hline 5 & Randangan & $1.515,03$ & $1.469,97$ & 0 & 436,64 & $4.508,31$ \\
\hline
\end{tabular}




\begin{tabular}{|l|l|c|c|c|c|c|}
\hline 6 & Wanggasari & $1.131,72$ & $1.420,47$ & 0 & 568,19 & $3.120,38$ \\
\hline 7 & Lemito & $1.133,28$ & 0 & 0 & 330,76 & $1.464,04$ \\
\hline 8 & $\begin{array}{l}\text { Popayato } \\
\text { Timur }\end{array}$ & 458,31 & 0 & 0 & 257,71 & 716,02 \\
\hline 9 & Popayato & 549,14 & 0 & 0 & 354,64 & 903,78 \\
\hline 10 & $\begin{array}{l}\text { Popayato } \\
\text { Barat }\end{array}$ & 712,34 & 0 & 0 & 363,28 & $1.075,62$ \\
\hline \multicolumn{2}{|c|}{ Grand Total } & $\mathbf{6 . 8 0 4 , 5 9}$ & $\mathbf{3 . 2 0 4 , 3 0}$ & $\mathbf{2 5 , 3 3}$ & $\mathbf{5 . 5 6 6 , 4 6}$ & $\mathbf{1 5 . 6 0 0 , 8 1}$ \\
\hline
\end{tabular}

Sumber: Kesatuan Pengelolaam Hutan Provinsi Gorontalo(2017)

Data dari Kesatuan Pengelolaan Hutan Provinsi Gorontalo menunjukkan 8.233 hektare hutan mangrove di wilayah kabupaten Pohuwato sudah beralih fungsi menjadi tambak. Kawasan hutan mangrove di pesisir Kabupaten Pohuwato Provinsi Gorontalo menjadi salah satu kawasan penyangga pesisir Teluk Tomini. Luas tutupan hutan mangrove di kawasan ini makin menurun, tercatat dari tahun 1988 seluas 13.243,33 Ha, dan di tahun 2010 tinggal 7.420,73 Ha (Djamaluddin R, 2011). Terdapat kecenderungan makin menurunnya luas tutupan mangrove ini hingga tahun 2014 akibat alih fungsi lahan yang terus terjadi. Berikut ini data kawasan hutan mangrove yang beralih fungsi menjadi tambak :

Tabel. 2

Luas Kawasan Hutan Mangrove Yang Beralih Fungsi Menjadi Tambak Di Kabupaten Pohuwato

\begin{tabular}{|l|l|c|c|c|c|c|}
\hline No & Kecamatan & $\begin{array}{c}\text { Hutan } \\
\text { Lindung }\end{array}$ & $\begin{array}{c}\text { Cagar } \\
\text { Alam }\end{array}$ & $\begin{array}{c}\text { Hutan } \\
\text { Produksi }\end{array}$ & APL & $\begin{array}{c}\text { Grand } \\
\text { Total }\end{array}$ \\
\hline 1 & Paguat & 95,46 & 0 & 12,72 & 50,73 & 158,92 \\
\hline 2 & Marisa & 0 & 1,39 & 0,58 & 196,47 & 198,44 \\
\hline 3 & Duhiadaa & 357,88 & 0 & 0 & 621,10 & 978,99 \\
\hline
\end{tabular}




\begin{tabular}{|c|c|c|c|c|c|c|}
\hline 4 & Patilanggio & 60,48 & 0 & 0 & 276,30 & 336,79 \\
\hline 5 & Randangan & 145,55 & 939,08 & 0 & 955,19 & $2.039,82$ \\
\hline 6 & Wanggasari & 934,28 & $1.104,65$ & 0 & 245,01 & $2.283,94$ \\
\hline 7 & Lemito & 414,01 & 0 & 0 & 86,88 & 500,89 \\
\hline 8 & $\begin{array}{l}\text { Popayato } \\
\text { Timur }\end{array}$ & 0 & 0 & 0 & 0,32 & 0,32 \\
\hline 9 & Popayato & 346,21 & 0 & 0 & 327,73 & 673,95 \\
\hline 10 & $\begin{array}{l}\text { Popayato } \\
\text { Barat }\end{array}$ & 191,89 & 0 & 0 & 315,70 & 507,59 \\
\hline \multicolumn{2}{|c|}{ Grand Total } & $2.545,77$ & $2.045,12$ & 13,30 & $3.075,46$ & $7.679,64$ \\
\hline
\end{tabular}

Sumber : Kesatuan Pengelolaam Hutan Provinsi Gorontalo (2017)

Berdasarkan tabel diatas kawasan hutan mangrove di Kabupaten Pohuwato sebagian besar sudah beralih fungsi menjadi usaha tambak, hal ini dapat berpengaruh menurunnya kondisi kualitas lingkungan di Kabupaten Pohuwato. Alih fungsi kawasan mangrove menjadi areal tambak menjadi penyebab utama berkurangnya luas kawasan, selain penebangan mangrove dalam skala kecil untuk kayu bakar, dijadikan arang dan bahan bangunan rumah oleh penduduk. Aktivitas perusakan kawasan hutan mangrove ini telah berdampak hilangnya fungsi ekosistem mangrove sebagai penyangga ekosistem pesisir lainnya, intrusi air laut dan menurunnya sumberdaya perikanan.

Wawancara dengan Bapak Usman Taue, S.Hut sebagai Plt. Kepala Bagian Tata Usaha KPH Provinsi Gorontalo Unit I dan II di Kabupaten Pohuwato, beliau menjelaskan pembukaan usaha tambak di Kabupaten Pohuwato dimulai sejak tahun 1977 diawali dengan usaha tambak garam seluas 70 hektar di bawah prakarsa pemerintah Kabupaten Gorontalo pada tahun 1977, ketika itu masih termasuk dalam wilayah Provinsi Sulawesi Utara. Usaha tambak garam yang awalnya di prakarsai oleh pemerintah 
tersebut, sejak tahun 1980 sampai sekarang berkembang menjadi tambak ikan dan udang. Alasan pembukaan lahan dan perluasan areal tambak hanya bermodalkan Surat Keterangan Hak Buka Lahan dari Kepala Desa dan Camat. Pembukaan atau pembuatan lahan mangrove yang dijadikan areal tambak sebelumnya bersifat tradisional tetapi sekarang telah menggunakan alat berat seperti escavator. Hal tersebut dapat mengakibatkan makin rusaknya ekosistem mangrove di Kabupaten Pohuwato.

Lebih lanjut Beliau menjelaskan perubahan kawasan hutan mangrove yang dijadikan usaha tambak semakin meluas yaitu terdapat dalam kawasan hutan lindung, cagar alam, hutan produksi, dan APL. Berdasarkan Perda Mangrove pada pasal 10 tentang penetapan kawasan hutan mangrove di bagi menjadi : kawasan lindung, kawasan lindung terbatas, kawasan sempadan sungai dan pantai, dan kawasan budidaya perikanan tumpang sari. Ia menjelaskan kawasan budidaya yang masuk dalam areal penggunaan lain (APL) diperbolehkan untuk usaha tambak dengan model tumpang sari tetapi harus dengan izin pemerintah dan dilarang mengembangkan tambak-tambak baru dengan cara penebangan mangrove secara liar. (hasil wawancara tanggal 6 Juni 2017)

Dalam masalah perizinanan usaha tambak di kawasan budidaya (APL) menurut Bapak Jumadi Giono, SP, Msi sebagai Kepala Bidang Pengendalian Pencemaran dan Kerusakan Lingkungan Hidup di Dinas Lingkungan Hidup Kabupaten Pohuwato, Ia menjelaskan bahwa dalam kawasan budidaya (APL) diperbolehkan membuka usaha tambak dengan syarat harus mendapat izin usaha dari pemerintah. Tetapi menurut beliau semua usaha tambak yang ada di kawasan budidaya (APL) tidak memiliki izin usaha maupun izin lingkungan. Dalam hal penegakan hukum terhadap para penambak sudah dilakukan tetapi masih perlu ditingkatkan baik tindakan preventif maupun represif. Lebih lanjut Ia menjelaskan dalam penegakan hukum administrasi terhadap usaha tambak di kawasan budidaya yang tidak memiliki izin dan semakin bertambahnya usaha-usaha 
tambak yang baru, Pemerintah Kabupaten Pohuwato mengeluarkan teguran tertulis berupa Istruksi Bupati sebanyak 3 kali sebagai berikut :

a. Instruksi Bupati Pohuwato Nomor 522/PEM/1057/X/2010 tentang Pelarangan Pembukaan Lahan Tambak di Kawaan Hutan Mangrove.

b. Instruksi Bupati Pohuwato Nomor 01 Tahun 2012 tentang Larangan Pembukaan Lahan Tambak di Kawasan Hutaan Mangrove.

c. Instruksi Bupati Pohuwato Nomor 522/PEM/742/X/2014 tentang Penegasan Pelarangan Pembukaan/Renovasi Tambak di Kawasan Hutan Mangrove.

Setelah dikeluarkannya Instruksi Bupati tersebut tidak ada kesadaran dari masyarakat maupun pelaku usaha untuk mematuhi aturan untuk tidak membuka tambak-tambak baru tanpa izin dari pemerintah. Sedangkan penegakan hukum untuk kawasan hutan lindung, cagar alam dan hutan produksi yang sudah beralih fungsi menjadi tambak Pemerintah Kabupaten Pohuwato bersama Pemerintah Provinsi dan Aparat Kepolisian Polda Gorontalo turun langsung menindak para pelaku perusakan hutan mangrove dengan cara menebang secara liar menggunakan alat berat seperti escavator. (Wawancara tanggal 14 Juni 2017)

Langkah selanjutnya yang dilakukan pemerintah Kabupaten Pohuwato dalam melindungi kawasan hutan mangrove yang semakin rusak akibat perambahan secara besar-besaran dengan mengeluarkan beberapa Peraturan Daerah diantaranya Peraturan Daerah Nomor 13 Tahun 2013 tentang Pengelolaan Ekosistem Mangrove, Peraturan Daerah Nomor 12 Tahun 2013 tentang Pengelolaan Wilayah Pesisir dan PulauPulau Kecil dan Peraturan Daerah Nomor 9 Tahun 2015 tentang Perlindungan dan Pengelolaan Lingkungan hidup di Kabupaten Pohuwato.

2. Penegakan Hukum Administrasi Terhadap Alih Fungsi Hutan Mangrove Di Kabupaten Pohuwato 
Mas Achmad Santosa menyatakanbahwa perangkat-perangkat penegakan hukum administrasi dalam sebuah sistem hukum dan pemerintahan paling tidak harus meliputi lima perangkat yang merupakan prasyarat awal dari efektifitas penegakan hukum administrasi di bidang lingkungan hidup. Kelima perangkat itu sebagai berikut: (Moh. Hasyim, 2004: 27)

a. Izin yang di dayagunakan sebagai perangkat pengawasan dan pengendalian.

b. Persyaratan dalam izin dengan merujuk pada AMDAL, standar baku mutu lingkungan, peraturan perundang-undangan.

c. Mekanisme pengawasan penataan.

d. Keberadaan pejabat pengawasan (inspektur yang memadai baik kuantitas maupun kualitasnya).

e. Sanksi administrasi

Penegakan hukum administrasi di bidang lingkungan hidup memiliki beberapa manfaat strategis dibandingkan dengan perangkat hukum lainnya (perdata dan pidana) yaitu sebagai berikut: (Syahrul Mahmud, 2012: 182), Pertama, Penegakan hukum administrasi di bidang lingkungan hidup dapat dioptimalisasikan sebagai perangkat pencegahan (preventif). Kedua, Penegakan hukum administrasi yang bersifat pencegahan dapat lebih efisien dari sudut pembiayaan dibandingkan penegakan hukum pidana dan perdata. Ketiga, Penegakan hukum administrasi lebih memiliki kemampuan mengundang partisipasi masyarakat.partisipasi masyarakat dilakukan mulai dari proses perizinan, pemantauan penataan/pengawasan, dan partisipasi dalam mengajukan keberatan dan meminta pejabat tata usaha negara untuk memberlakukan sanksi administrasi.

Dalam Perda Kabupaten Pohuwato tentang PPLH berisi ketentuan pengelolaan lingkungan hidup dan pencegahan perusakan terhadap lingkungan, juga mengatur tentang ketentuan sanksi administrasi terdiri dari teguran tertulis, paksaan pemerintah, pembekuan izin lingkungan, dan 
pencabutan izin lingkungan. Ketentuan sanksi administrasi ini dimaksudkan agar setiap kegiatan usaha yang dilakukan oleh korporasi maupun perseorangan dan berdampak pada lingkungan harus taat pada aturan yang ditetapkan pemerintah, hal ini agar setiap pelaku usaha tertib dan tetap memperhatikan kelestarian lingkungan.

Terkait alih fungsi hutan mangrove yang dijadikan usaha pertambakan baik yang ada di dalam kawasan hutan maupun di luar kawasan hutan, dalam Perda Kabupaten Pohuwato tentang Pengelolaan Ekositem Mangrove pada Pasal 10 dijelasakan kawasan hutan mangrove ditetapkan sebagai berikut : Kawasan Lindung, Kawasan Lindung Terbatas, Kawasan Sempadan Sungai dan Pantai, dan Kawasan Budidaya Perikanan Tumpang Sari. Pada Pasal 11 dijelasakan bahwa usaha tambak dapat dilakukan dikawasan lindung terbatas dan kawasan budidaya. Dalam kawasan lindung terbatas disebutkan budidaya ikan/udang dengan model tambak tumpang sari dalam luasan terbatas yaitu tidak lebih dari 5\% dari total luas hutan lindung terbatas. Sedangkan di kawasan budidaya yang masuk dalam APL dapat dilakukan budidaya ikan/udang dengan model tambak tumpang sari (Sylvo-fishery).

Kegiatan usaha tambak dalam kawasan hutan mangrove seperti yang dijelaskan pada Pasal 11 hanya boleh dilakukan dikawasan lindung terbatas dan kawasan budidaya atas izin pemerintah Kabupaten Pohuwato. Tetapi pada kenyataan dilapangan usaha tambak terdapat di semua kawasan hutan mangrove dan pada dasarnya semua usaha tidak memiliki izin dalam hal ini AMDAL dan UKL-UPL. Padahal dalam UUPPLH sudah dijelaskan bahwa setiap usaha atau kegiatan yang berdampak pada lingkungan hidup wajib memiliki AMDAL dan UKL-UPL.

Penegakan hukum administrasi oleh pemerintah Kabupaten Pohuwato terhadap pelaku usaha tambak belum dilaksanakan secara optimal. Hal ini disebabkan karena tidak jelasnya masalah perizinan bagi pelaku usaha di kawasan hutan mangrove khususnya kawasan budidaya. Dalam Perda Kabupaten Pohuwato tentang Pengelolaan Ekosistem 
Mangrove tidak dijelasakan syarat melakukan usaha di kawasan hutan mangrove harus memilki izin lingkungan sebagai syarat memperoleh izin usaha.

Berdasarkan wawancara dengan Bapak Ismet Hunowu, ST, sebagai Kepala Seksi Perencanaan dan Kajian Dampak Lingkungan menjelaskan dalam hal izin usaha di kawasan hutan mangrove belum ada usaha tambak yang memiliki AMDAL maupun UKL-UPL akan tetapi dalam pembukaan usaha tambak pelaku usaha diwajibkan melakukan permohonan izin pembuatan tambak di kawasan budidaya (APL) melalui Dinas Kehutanan Kabupaten Pohuwato tetapi sekarang Dinas Kehutanan tidak ada lagi di Pemda Kabupaten tetapi sudah di ambil alih oleh Pemda Provinsi. Namun sekarang di Dinas Lingkungan Hidup sudah ada Seksi Kehutanan yang melaksanakan urusan kehutanan. (Wawancara tanggal 15 Juni 2017)

Pada Peraturan Menteri Lingkungan Hidup Nomor 5 Tahun 2012 tentang Daftar Jenis Usaha Dan/Atau Kegiatan yang wajib memiliki Analisis Mengenai Dampak Lingkungan Hidup disebutkan bahwa usaha budidaya tambak udang/ikan lebih dari 50 ha wajib memiliki AMDAL. Oleh karena itu seharusnya pemerintah Kabupaten Pohuwato dalam hal memberikan izin pembukaan usaha tambak mewajibkan pelaku usaha memiliki AMDAL.

Penegakan hukum administrasi terhadap pelaku usaha tambak di kawasan hutan mangrove menurut Ibu Suci Juliandari Akuba, SH, MH sebagai Kepala Seksi Pengaduan, Penyelesaian Sengketa dan Penegakan Hukum Lingkungan, selama ini pemerintah Kabupaten Pohuwato sudah menerapkan sanksi administrasi berupa teguran tertulis dengan mengeluarkan Instruksi Bupati Pohuwato sebanyak tiga kali yang berisi tentang larangan pembukaan usaha tambak dikawasan hutan mangrove. Tetapi masyarakat ataupun pelaku usaha tidak mematuhi larangan tersebut dan masih terus menbuka lahan baru untuk di jadikan tambak. Menurut beliau perusakan kawasan hutan mangrove yang dijadikan tambak sudah berlangsung lama dan hal ini terjadi juga di kawasan hutan lindung dan 
cagar alam sebab itu pemerintah sulit untuk menertibkan pelaku perusakan kawasan karena pelaku usaha mengaku mempunyai akta jual beli lahan dan surat izin dari kepala desa. Untuk itu pemerintah bekerja sama dengan pihak kepolisian mengambil langkah menjatuhkan sanksi pidana terhadap pelaku perusakan dan perambahan kawasan hutan diantaranya oknum kepala desa dan pelaku usaha sudah dilakukan penyidikan dan penahanan. (Wawancara tanggal 15 Juni 2017)

Berdasarkan permasalahan di atas peneliti berpendapat kurang seriusnya pemerintah dalam pengelolaan dan perlindungan ekosistem mangrove hal ini dibuktikan dengan tidak ada satupun usaha tambak di kawasan budidaya (APL) yang memiliki izin usaha maupun izin lingkungan. Selain itu dalam Perda Kabupaten Pohuwato tentang Pengelolaan Ekosistem Mangrove ditetapkan bahwa usaha tambak dikawasan budidaya harus menggunakan model tumpang sari. Tetapi pada faktanya pelaku usaha semakin banyak membuka tambak-tambak baru dengan melakukan penebangan secara liar. Tidak ada kesadaran dari masyarakat maupun pelaku usaha untuk mengurus izin lingkungan karena setiap aktivitas pembangunan yang dilakukan dalam berbagai bentuk usaha dan/atau kegiatan akan menimbulkan dampak terhadap lingkungan.

Dalam pengelolaan lingkungan hidup, pengaturan mengenai perizinan sesuai dengan UUPPLH merupakan perangkat hukum yang bersifat preventif. Upaya preventif dalam rangka pengendalian dampak lingkungan hidup perlu dilaksanakan dengan mendayagunakan secara maksimal instrumen pengawasan dan perizinan. Sedangkan dalam hal pencemaran dan kerusakan lingkungan hidup yang sudah terjadi, perlu dilakukan upaya represif berupa penegakan hukum yang efektif, konsekuen, dan konsisten. Sehingga perlu adanya suatu sistem hukum perlindungan dan pengelolaan lingkungan hidup yang jelas, tegas, dan menyeluruh untuk menjamin kepastian hukum sebagai landasan bagi perlindungan dan pengelolaan sumber daya alam serta kegiatan pembangunan lainnya. 
Izin lingkungan harus dimiliki tidak hanya untuk kegiatan usaha yang berdampak pada lingkungan hidup yang mewajibkan harus memiliki dokumen AMDAL tetapi juga pada kegiatan usaha yang tidak berdampak penting terhadap lingkungan hidup harus memiliki dokumen UKL-UPL yang diperlukan bagi proses pengambilan keputusan tentang penyelenggaraan usaha dan/atau kegiatan. Selain itu izin lingkungan memberikan kepastian hukum pada pengusaha bahwa sejak awal mereka telah memenuhi semua ketentuan di bidang lingkungan hidup. Oleh karena itu setiap usaha harus mendapat izin lingkungan sebelum memperoleh izin usaha, sebab izin lingkungan bertujuan memberikan perlindungan terhadap lingkungan hidup yang lestari dan berkelanjutan, meningkatkan upaya pengendalian kegiatan usaha yang berdampak negatif pada lingkungan hidup, memberikan kejelasan prosedur, mekanisme dan koordinasi antar instansi dalam hal penyelenggaraan perizinan untuk kegiatan usaha, dan memberikan kepastian hukum dalam suatu kegiatan usaha.

Melihat permasalahan diatas harusnya pemerintah Kabupaten Pohuwato memberikan kepastian hukum terkait izin lingkungan kepada masyarakat dan pelaku usaha. Karena perizinan mempunyai fungsi sebagai instrumen rekayasa pembangunan dimana pemerintah dapat membuat regulasi dan keputusan yang memberikan insentif bagi pertumbuhan sosial ekonomi, disamping itu perizinan juga sebagai fungsi keuangan (budgeting), yaitu menjadi sumber pendapatan bagi pemerintah daerah. Faktanya usaha tambak di kawasan hutan mangrove menghasilkan puluhan hingga ratusan juta dan hal ini menjadi penyebab makin banyak usaha-usaha tambak baru yang dilatar belakangi faktor ekonomi sehingga melakukan perambahan terhadap kawasan hutan. Untuk itu pentingnya perizinan lingkungan sebagai perangkat pencegahan dan pengendalian kerusakan lingkungan dimana masyarakat ikut berperan aktif didalamnya.

Dapat disimpulkan penegakan sanksi administrasi oleh pemerintah secara taat dan konsisten sesuai dengan kewenangan yang ada akan berdampak bagi penegakan hukum, dalam rangka menjaga kelestarian 
fungsi lingkungan hidup. Oleh karena itu penegakan sanksi administrasi merupakan garda terdepan dalam penegakan hukum lingkungan (premium remedium) dan jika sanksi administrasi di nilai tidak efektif maka bisa dipergunakan sanksi pidana sebagai upaya terakhir (ultimum remedium).

\section{Simpulan}

Penegakan hukum administrasi terhadap usaha tambak dikawasan hutan mangrove Di Kabupaten Pohuwato belum optimal karena semua usaha yang ada dikawasan budidaya tidak memiliki izin lingkungan. Masalah perizinan pemanfaatan kawasan hutan mangrove belum menjadi perhatian utama pemerintah karena dalam Perda Pengelolaan Ekosistem Mangrove yang dibuat dalam rangka mencegah dan menghentikan kerusakan hutan mangrove tidak mengatur secara jelas perizinan pemanfaatan kawasan hutan untuk dijadikan tambak.

\section{E. Saran}

1. Untuk DLH Kabupaten Pohuwato diperlukan adanya peningkatan sumber daya manusia yang terampil dan memiliki pengetahuan tentang penanganan masalah-masalah dibidang lingkungan hidup agar dalam penegakan hukum administrasi dapat dilakukan secara optimal.

2. Pemerintah Kabupaten Pohuwato melalui DLH Kabupaten Pohuwato perlu melakukan sosialisasi untuk memberikan pemahaman kepada masyarakat pelaku usaha dikawasan hutan mangrove terhadap peraturan perundang-undangan di bidang lingkungan hidup khususnya mengenai pentingnya kegiatan usaha memiliki izin lingkungan dalam rangka melibatkan masyarakat untuk menjaga dan mengendalikan kerusakan terhadap lingkungan.

\section{F. Daftar Pustaka}

Maret Priyanta. 2015. "Pembaharuan dan Harmonisasi Peraturan Perundangundangan Bidang Lingkungan dan Penataan Ruang Menuju Pembangunan Berkelanjutan". Hasanuddin Law Riview Vol. 1 Issue 3. Desember. 
Maret Priyanta. 2012. "Penerapan Tindak Pidana Lingkungan Bagi Korporasis dalam Penegakan Hukum Lingkungan di Indonesia". Law Review. Fakultas Hukum Unpad Bandung. Vol XI No. 3. Maret.

Muazzin dan Tinianus. 2010. "Alih Fungsi Hutan Mangrove di Kabupaten Aceh Tamiang”. Jurnal Kanun No. 52. Edisi Desember.

Moh. Hasyim. 2004. "Penegakan Hukum Administrasi Terhadap Izin Usaha Industri Sebagai Instrumen Yuridis Penataan Lingkungan Hidup (Studi tentang Pengawasan dan Penerapan Sanksi Adminstrasi Di Kota Semarang)". Jurnal Hukum Ius Quia Iustum. Edisi Nomor 27 Volume 11

Rignolda Djamaluddin. 2011. "Survei Kondisi Ekosistem Mangrove di Kabupaten Pohuwato. Program Teluk Tomini (SUSCLAM) Tomini Bay Sustainable Coastal and Livelihoods Management Project CIDA". Makalah Atlas Mangrove Teluk Tomini.

Setiono. 2005. Pembaharuan Metodologi Penelitian Hukum, Surakarta: Sebelas Maret University.

Suttan Iskandar. 2011. "Aktualisasi Prinsip Hukum Pelestarian Fungsi Lingkungan Hidup dalam Kebijakan Perubahan Peruntukan, Fungsi, dan Penggunaan Kawasan Hutan”. Fakultas Hukum Universitas Bengkulu. Jurnal Dinamika Hukum Vol. 11 No. 3. September.

Syahrul Machmud. 2012. Penegakan Hukum Lingkungan; Penegakan Hukum Administrasi, Hukum Perdata, dan Hukum Pidana Menurut UndangUndang No 32 Tahun 2009. Yogyakarta: Graha Ilmu.

Undang-Undang Nomor 32 Tahun 2009 Tentang Perlindungan dan Pengelolaan Lingkungan Hidup

Undang-Undang Nomor 41 Tahun 1999 Tentang Kehutanan

Undang-Undang Nomor 23 Tahun 2014 Tentang Pemerintahan Daerah

Peraturan Pemerintah Nomor 27 Tentang Izin Lingkungan

Peraturan Daerah Nomor 9 Tahun 2015 Tentang Perlindungan dan Pengelolaan Lingkungan Hidup Kabupaten POhuwato

Peraturan Daerah Nomor 13 Tahun 2013 Tentang Pengelolaan Ekosistem Mangrove

http://www.antaranews.com/berita/504319/8233-hektare-lahan-mangrovepohuwato-beralih-fungsi, diakses tanggal 17 Maret 2017 